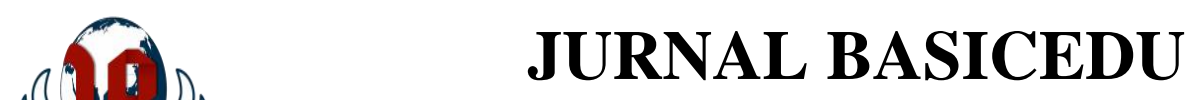

Volume 5 Nomor 5 Tahun 2021 Halaman 3242 - 3249

Research \& Learning in Elementary Education https://jbasic.org/index.php/basicedu

\title{
Pengaruh Strategi Pembelajaran Information Search terhadap Kemampuan Pemahaman Belajar Matematika Siswa
}

\author{
Putri Maisyarah Ammy \\ Pendidikan Matematika, Universitas Muhammadiyah Sumatera Utara \\ E-mail: putrimaisyarah@umsu.ac.id
}

\begin{abstract}
Abstrak
Pada penelitian ini terdapat permasalahan, yaitu tingkat pemahaman siswa yang masih rendah. Penelitian ini bertujuan: (1) Untuk mengetahui apakah terdapat pengaruh pembelajaran Information Search terhadap kemampuan pemahaman belajar matematika siswa dan (2) Untuk mengetahui seberapa besar pengaruh strategi pembelajaran Information Search terhadap kemampuan pemahaman belajar matematika siswa. Penelitian ini termasuk dalam eksperimen semu. Populasi penelitian adalah seluruh kelas X SMK PAB Helvetia Medan dan yang menjadi sampel penelitian adalah kelas X AK 1 sebagai kelas eksperimen dengan jumlah siswa 40 orang dan X AK 2 sebagai kelas kontrol dengan jumlah 40 siswa. Teknik pengumpulan data pada penelitian menggunakan tes Pre-Test dan Post-test untuk mengukur nilai rata-rata kemampuan pemahaman belajar matematika siswa. Sedangkan teknik analisis data dengan menggunakan uji prasyarat: Uji Normalitas, Uji Homogenitas, serta Uji Hipotesis: Uji-T. Pada hasil analisis data untuk uji prasyarat menyatakan bahwa data pada penelitian ini berdistribusi normal dan homogen. Sedangkan pada uji hipotesis Uji-T didapat bahwa $t_{\text {hitung }}$ $=2,8095>\mathrm{t}_{\text {tabel }}=1,9908$, sehingga Ha diterima. Hal ini berarti ada pengaruh strategi pembelajaran Information Search terhadap kemampuan pemahaman belajar matematika pada siswa.
\end{abstract}

Kata Kunci: Strategi Pembelajaran, Information Search, Pemahaman Siswa.

\begin{abstract}
In this study there are problems, namely the level of student understanding is still low. This study aims: (1) to find out whether there is an effect of Information Search learning on students' understanding of mathematics learning abilities and (2) to find out how much influence Information Search learning strategies have on students' mathematics learning understanding abilities. This research is included in a quasi-experimental. The research population was all class X SMK PAB Helvetia Medan and the research sample was class X AK 1 as the experimental class with 40 students and X AK 2 as control class with 40 students. The data collection technique in this study used Pre-Test and Post-test tests to measure the average value of students' mathematics learning comprehension abilities. While the data analysis techniques using prerequisite tests: Normality Test, Homogeneity Test, and Hypothesis Testing: T-Test. The results of the data analysis for the prerequisite test stated that the data in this study were normally distributed and homogeneous. Meanwhile, in the T-Test hypothesis test, it was found that $t_{\text {count }}=2.8095 t_{\text {table }}=1.9908$, so Ha was accepted. This means that there is an influence of the Information Search learning strategy on the ability to understand mathematics in students.
\end{abstract}

Keywords: Learning Strategy, Information Search, Student Understanding.

Copyright (c) 2021 Putri Maisyarah Ammy

Corresponding author :

Email : putrimaisyarah@umsu.ac.id

DOI : https://doi.org/10.31004/basicedu.v5i5.1294

ISSN 2580-3735 (Media Cetak)

ISSN 2580-1147 (Media Online) 
3243 Pengaruh Strategi Pembelajaran Information Search terhadap Kemampuan Pemahaman Belajar Matematika Siswa - Putri Maisyarah Ammy

DOI: https://doi.org/10.31004/basicedu.v5i5.1294

\section{PENDAHULUAN}

Pendidikan merupan proses memanusiakan anak, sehingga potensinya menjadi aktual dalam kematangan dan kemandirian hidupnya. Pendidikan pada dasarnya adalah usaha sadar untuk menumbuhkembangkan peserta didik dengan cara mendorong dan menfasilitasi kegiatan belajar mereka. Secara detail, dalam Undang-Undang RI Nomor 20 Tahun 2003 tentang Sistem Pendidikan Nasional Bab 1 Pasal 1, yaitu Pendidikan didefinisikan sebagai usaha sadar dan terencana untuk mewujudkan suasana belajar dan proses pembelajaran agar peserta didik secara aktif mengembangkan potensi dirinya untuk memiliki kekuatan spiritual keagamaan, pengendalian diri, kepribadian, kecerdasan, akhlak mulia, serta ketrampilan yang diperlukan dirinya, masyarakat, bangsa dan negara. Oleh karena itu dibutuhkan secara sadar dan kemauan kuat dari setiap individu tersebut untuk berperan aktif dalam menumbuhkan potensi sumber daya manusia itu sendiri.

Menurut Bloom (1956), dalam dunia pendidikan ada tiga tujuan pendidikan yang sangat dikenal dan diakui oleh para pendidikan, yaitu ranah kognitif, afektif dan psikomotorik. Ranah kognitif merupakan ranah psikologis siswa yang terpenting sekaligus meupakan sumber pengendali dari ranah afektif dan psikomotor. Ranah kognitif juga merupakan kemampuan yang selalu dituntut kepada anak diidk untuk dikuasai. Karena penguasaan kemampuan ini menjadi dasar bagi penguasaan ilmu pengetahuan, ranah kognitif ini dapat dipelajari oleh siswa-siswa dengan guru, kemampuan ini lebih banyak mengajak siswa berfikir dengan memberi bahan materi pelajaran yang siswa dapat memecahkannya, baik dalam kelas maupun didalam kehidupan sehari-hari di luar sekolah.

Proses pembelajaran membutuhkan strategi yang tepat, kesalahan menggunakan strategi dapat menghambat tercapainya tujuan pembelajaran. Pembelajaran merupakan suatu proses dimana terjadi interaksi antara guru dengan siswa, sehingga pesan dapat disampaikan dengan baik. Seiring dengan berkembangnya kurikulum di Indonesia, paradigma pembelajaran turut berkembang dari Teacher Centered Learning (TCL) menuju Student Centered Learning. Menurut Festiawan (2020), mendefinisikan pembelajaran sebagai suatu aktivitas menorganisasi atau mengatur lingkungan sebaik-baiknya dan menghubungkannya dengan anak didik sehingga terjadi proses belajar.

Pada kurikulum 2013 posisi guru dalam pembelajaran adalah sebagai fasilitator. Pendekatan yang diterapkan pada proses pembelajaran menuntut siswa untuk dapat berpikir kritis dan mencari sendiri solusi dari permasalahan serta materi yang dipelajari. Permasalahan yang sering dialami siswa adalah lemahnya pemahaman siswa dalam proses pembelajaran matematika. Menurut Tri Murdiyanto (2014), Pembelajaran matematika memiliki tingkat kesulitan dan keabstrakan konsep yang lebih tinggi tentu memerlukan cara dan metode komunikasi yang berbeda dengan mata pelajaran lain. Sehingga perlu dilakukan cara agar materi dalam pembelajaran matematika dapat tersampaikan dan dipahami dengan baik oleh siswa.

Berdasarkan observasi yang dilakukan di kelas X SMK BM PAB Helvetia Medan, ditemukan masih banyak siswa yang belum mengerti tentang pokok bahasan persamaan kuadrat. Dari observasi yang dilakukan peneliti pada siswa yang berjumlah 42 orang, hanya 18 siswa yang tuntas atau mendapatkan nilai di atas kategori paham. Sehigga, dapat dikatakan bahwa siswa kelas X-Ak termasuk dalam kategori tidak paham dalam pokok bahasan yang diajarkan.

Hasil dari wawancara dengan kelas X-Ak yang mendapat nilai rendah, siswa menyatakan bahwa "Umumnya matematika adalah pelajaran yang sulit, menguras otak, membosankan dan membuat pusing sehingga membuat malas untuk mengulang pelajaran di rumah. Kami juga sering merasa bosan saat belajar, yang akhirnya membuat kami lebih senang membaca buku-buku lain atau bercerita dengan teman sebangku daripada harus mendengarkan guru menjelaskan materi pelajaran di depan kelas".

Pelaksanakan pembelajaran matematika memerlukan beberapa kecakapan guru untuk menentukan suatu strategi pembelajaran yang tepat, baik untuk materi maupun situasi dan kondisi pembelajaran. Sehingga 
3244 Pengaruh Strategi Pembelajaran Information Search terhadap Kemampuan Pemahaman Belajar Matematika Siswa - Putri Maisyarah Ammy

DOI: https://doi.org/10.31004/basicedu.v5i5.1294

pembelajaran tersebut dapat merangsang siswa untuk memperoleh kompetisi yang diharapkan. Salah satu kompetisi tersebut adalah meningkatkan kemampuan pemahaman matematik siswa.

Kemampuan guru dalam memahami dan melaksanakan strategi juga sangat berpengaruh terhadap kemampuan belajar siswa. Kenyataan yang banyak dijumpai pada siswa di SMK BM PAB Helvetia Medan, khusunya kelas X-Ak adalah pembelajaran yang masih berpusat pada guru sehingga mengakibatkan kegiatan belajar kurang efektif dikarekan tingkat pemahaman siswa rendah. Salah satu faktor penyebabnya adalah pembelajaran yang masih berorientasi pada target pengasaan materi dan pengembangan aspek kognitif yang mentrasfer pengetahuan dari guru ke siswa yang diikuti dengan latihan-latihan dan tidak membentuk pemahaman siswa dalam belajar dengan baik. Keterlibatan siswa juga kurang terlihat secara nyata, sehingga pembelajaran pun tidak efektif.

Sebagaimana telah dijelaskan sebelumnya, bahwa strategi pembelajaran yang digunakan guru selama ini bersifat konvensional, seperti strategi tanya jawab, ceramah, latihan dan pemberian tugas. Strategi yang diterapkan oleh guru belum tentu sesuai dengan materi yang diajarkan, sehingga menyulitkan siswa dalam memahami materi yang diajarkan. Padahal, tujuan utama dari strategi adalah untuk memudahkan siswa dalam menerima bahan ajar.

Strategi pembelajaran merupakan hal yang perlu diperhatikan guru dalam pembelajaran. Menurut Aulia Rahman (2018), strategi pembelajaran merupakan hal yang perlu diperhatikan oleh seorang guru dalam proses pembelajaran. Paling tidak ada 3 jenis strategi yang berkaitan dengan pembelajaran, yaitu strategi pengorganisasian, penyampaian, dan pengelolaan pembelajaran. Kemp (dalam Dewi Nurmala, 2018) menjelaskan bahwa strategi pembelajaran adalah suatu kegiatan pembelajaran yang harus dikerjakan oleh guru dan siswa agar tujuan pembelajaran dapat dicapai secara efektif dan efisien.

J.R. David (dalam Dewi Nurmala, 2018), Strategy a plan, method, or series of activities designed to achieves a particular educational goal, sehingga dapat diartikan sebagai suatu perencanaan yang berisi tentang rangkaian kegiatan yang didesain untuk mencapai tujuan pendidikan. Dalam mendesain suatu perencanaan hal yang dicermati adalah strategi pembelajaran dan susunan strategi dalam mencapai tujuan tertentu.

Berdasarkan akar permasalahan yang dikemukakan di atas, guru mencari suatu strategi yang dapat mengembangkan kemampuan belajar matematika siswa untuk menggunakan ide-ide dan konsep-konsep yang sudah mereka pelajari sebelumnya dalam menyelesaikan soal-soal terkait persamaan kuadrat. Sehingga peneliti mencoba menerapkan strategi pembelajaran Information Search dimana para siswa dituntut untuk bisa menjawab suatu pertanyaan dalam bentuk kelompok dengan adanya sumber belajar yang sudah disediakan oleh guru. Dalam kegiatan ini siswa akan mencari sendiri jawaban dari materi yang akan diajarkan, sehinggga siswa dapat secara perlahan meningkatkan pemahaman dalam pembelajaran matematika. Dengan adanya diskusi serta bimbingan oleh guru, maka diharapkan pemahaman siswa akan meningkat.

Menurut Silberman (dalam Purwanti, N. 2019), metode Information Search sama dengan ujian open book. Secara berkelompok siswa mencari informasi dan menjawab pertanyaan-pertanyaan yang diberikan kepada mereka. Strategi ini sangat membantu pelajaran untuk lebih menghidupkan materi yang dianggap membosankan. Strategi ini merupakan suatu strategi dalam pembelajaran, yang mana dalam strategi ini siswa dapat di arahkan untuk mencari informasi dari buku lain atau internet, strategi ini dapat di gunakan oleh guru dalam mendapatkan pemahaman siswa di dalam belajar, karena strategi ini menekankan keaktifan dari siswa selama dalam proses belajar mengajar, dengan keaktifan siswa tersebut suasana belajar di kelas akan lebih optimal dan kondusif, selain itu siswa juga akan lebih termotivasi untuk mencari tahu setiap permasalahan di dalam belajar, dengan motivasi dan keaktifan tersebut kemampuan pemahaman siswa juga akan menjadi lebih baik.

Kemampuan pemahaman merupakan suatu aspek yang sangat penting dalam pembelajaran matematika. Pemahaman merupakan landasan penting untuk menyelesaiakan persoalan-persoalan matematika maupun 
3245 Pengaruh Strategi Pembelajaran Information Search terhadap Kemampuan Pemahaman Belajar Matematika Siswa - Putri Maisyarah Ammy

DOI: https://doi.org/10.31004/basicedu.v5i5.1294

dalam kehidupan sehari-hari. Menurut Sumarmo (dalam Kesumawati, Nila. 2008), pemahaman diartikan dari kata understanding dimana derajat pemahaman ditentukan oleh tingkat keterkaitan suatu gagasan, prosedur atau fakta matematika dipahami secara menyeluruh jika hal-hal tersebut membentuk jaringan dengan keterkaitan yang tinggi.

Kemampuan pemahaman matematik merupakan kemampuan yang perlu dikuasai oleh siswa. Hal ini sejalan dengan maksud pembelajaran matematika yang tercantum dalam KTSP 2006 dan pada kurikulum 2013 (dalam Sugandi, dkk. 2018), antara lain: memahami pengetahuan matematika, menjelaskan keterkaitan antar pengetahuan atau logaritma, secara akurat, luwes dan efesien, mengkomunikasikan suatu ide atau gagasan dengan lambang, (tabel), atau sarana lain dalam memberi penjelasan suatu situasi atau masalah. Bloom (dalam Ferdianto, F. dkk. 2014), menyatakan bahwa pemahaman (comprehension) mengacu pada kemampuan untuk mengerti dan memahami sesuatu setelah sesuatu itu terlebih dahulu diketahui atau diingat dan memaknai arti dari materi yang dipelajari.

Menurut Sugandi, dkk. (2018), kemampuan pemahaman matematik merupakan suatu kemampuan yang perlu dikuasai dalam pembelajaran matematika, mempunyai arti bahwa konsep-konsep matematika tidak hanya berupa hapalan saja, namun bisa diserap kedalam pemikiran siswa, sehingga siswa dapat mengaplikasikan konsep-konsep tersebut dalam situasi dan keadaam yang lainnya. Pemahaman juga merupakan salah satu tujuan dari setiap materi yang akan diajarkan oleh guru, karena guru yang membimbing siswa dalam mencapai konsep tersebut.

Menurut Carin dan Sund (dalam Susanto, A. 2020), pemahaman merupakan kemampuan untuk menerangkan dan menginterpretasikan sesuatu, yang berarti bahwa seseorang telah memahami sesuatu atau telah memperoleh pemahaman akan mampu menerangkan atau menjelaskan kembali apa yang telah ia terima. Siswa dikatakan memahami konsep jika siswa mampu mendefinisikan konsep, mengidentifikasi dan memberi contoh atau bukan contoh dari konsep, mengembangkan kemampuan koneksi matematik antar berbagai ide, memahami bagaimana ide-ide matematik saling terkait satu sama lain sehingga terbangun pemahaman menyeluruh, dan menggunakan matematik dalam konteks di luar matematika. Sedangkan siswa dikatakan memahami prosedur jika mampu mengenali prosedur (sejumlah langkah-langkah dari kegiatan yang dilakukan) yang didalamnya termasuk aturan algoritma atau proses menghitung yang benar.

\section{METODE PENELITIAN}

Penelitian ini adalah penelitian eksperimen semu dengan desain Pre-Test dan Post-Test Only Control Design, dimana menggunakan Strategi Pembelajaran Information Search pada kelas eksperimen dan konvensional pada kelas kontrol.

Populasi adalah keseluruhan objek yang akan atau ingin diteliti (Syahrum dan Salim. (2012). Menurut Sugiyono. (2013), populasi adalah wilayah generalisasi yang terdiri atas, obyek atau subyek yang mempunyai kualitas dan karakteristik tertentu yang ditetapkan oleh peneliti untuk dipelajari dan kemudian ditarik kesimpulannya. Adapun yang menjadi populasi dalam penelitian ini adalah seluruh siswa kelas X SMK BM PAB Helvetia Medan yang berjumlah 120 siswa dari 3 kelas. Sampel adalah sebagian atau wakil populasi yang diteliti. Sedangkan sampel dalam penelitian ini sebanyak 80 siswa dari 2 kelas.

Adapun instrument yang digunakan dalam penelitian ini adalah tes kreativitas siswa. Tes atau alat adalah prosedur yang digunakan untuk mengetahui atau mengukur sesuatu dalam suasana, dengan cara aturanaturan yang sudah ditentukan, biasanya berupa sejumlah pertanyaan/soal yang diberikan untuk dijawab oleh subjek yang diteliti (siswa/guru). Dalam penelitian pendidikan matematika, instrumen tes biasanya digunakan untuk mengukur aspek kognitif, seperti prestasi belajar siswa, atau kemampuan matematis tertentu (Djemari, M. 2011). 
3246 Pengaruh Strategi Pembelajaran Information Search terhadap Kemampuan Pemahaman Belajar Matematika Siswa - Putri Maisyarah Ammy

DOI: https://doi.org/10.31004/basicedu.v5i5.1294

Tes pemahaman diberikan kepada peserta didik dalam bentuk post-test untuk mendapatkan data kognitif tentang pemahaman siswa dalam materi persamaan kuadrat peserta didik dari kelas kontrol dan eksperimen. Untuk mengetahui tingkat kemampuan pemahaman matematika siswa dalam menyelesaikan permasalahan matematika, maka diperlukan suatu rubrik penskoran kemampuan pemahaman matematika. Penskoran kemampuan pemahaman matematika siswa diberikan berdasarkan pedoman penskoran kemampuan pemahaman matematika siswa sebagai berikut: (Wardhani: 2010).

Tabel 1. Pedoman Penskoran Kemampuan Pemahaman Matematika

\begin{tabular}{lcl}
\hline \multicolumn{1}{c}{ Kemampuan Pemahaman Matematika } & Skor & \multicolumn{1}{c}{ Keterangan } \\
\hline Mengelaborasi & 1 & Menulis konsep dengan bahasa sendiri \\
\hline Mengembangkan & 1 & Membuat contoh serta non contoh dari konsep \\
\hline Memperinci & 1 & Menggunakan konsep untuk menyelesaikan soal \\
\hline
\end{tabular}

Siswa dikatakan paham, jika memiliki nilai akhir $\geq 70 \%$ dari total skor keseluruhan indikator pemahaman, persentase pemahaman matematika siswa dapat diperoleh dengan rumus:

$$
\text { Persentase Kemampuan Siswa }=\frac{\text { Skor siswa }}{\text { Skor maksimal }} \times 100 \% \quad \text { (Praja, dkk: 2021) }
$$

Data hasil kemampuan pemahaman matematik siswa akan dikategorikan menggunakan kategori menurut Suprihatin (dalam Praja, dkk: 2021) sebagai berikut:

Tabel 2. Kategori Kemampuan Pemahaman Matematik Siswa

\begin{tabular}{cc}
\hline Tingkat Pemahaman & Kriteria \\
\hline$>70 \%$ & Tinggi \\
\hline $55 \% \geq 70 \%$ & Sedang \\
\hline$\leq 55 \%$ & Rendah \\
\hline
\end{tabular}

Teknik analisis data bertujuan untuk mengelola data yang diperoleh dari penelitian, guna mendapatkan pertanggung jawaban kebenarannya. Adapun langkah-langkah yang dilakukan dalam menganalisa data penelitian ini adalah: Analisis Deskripsi Data. Adapun yang dilakukan dalam menganalisis data dalam penelitian ini adalah menghitung mean dan simpangan baku. Uji Prasayarat Analisa. Adapun yang dilakukan dalam uji analisa dalam penelitian ini adalah uji normalitas, homogenitas, dan hipotesis dengan uji t.

\section{HASIL DAN PEMBAHASAN}

Penelitian dilaksanakan di SMK PAB Helvetia Medan pada kelas X, dengan mengambil dua kelas sebagai sampel penelitian, yaitu kelas X-SMK Ak 1 yang berjumlah 40 siswa sebagai kelas eksperimen dan siswa kelas X-SMK Ak 2 yang berjumlah 40 siswa sebagai kelas kontrol. Pada kelas eksperimen, peneliti menerapkan model pembelajaran information search sedangkan pada kelas kontrol, peneliti menerapkan metode ceramah yang biasa dilakukan oleh guru.

Setelah dilakukan uji coba soal, selanjutnya diperoleh ketuntasan hasil belajar, maka di peroleh nilai rata-rata hasil belajar matematika siswa, sebagai berikut: 
3247 Pengaruh Strategi Pembelajaran Information Search terhadap Kemampuan Pemahaman Belajar Matematika Siswa - Putri Maisyarah Ammy

DOI: https://doi.org/10.31004/basicedu.v5i5.1294

Tabel 3. Data Post-Test Kelas Eksperimen dan Kelas Kontrol

\begin{tabular}{cccc}
\hline No & Statistika & Kelas Eksperimen & Kelas Kontrol \\
\hline 1 & N & 40 & 40 \\
\hline 2 & Jumlah nilai & 3313 & 3131 \\
\hline 3 & Rata-rata & 82,825 & 78,275 \\
\hline 4 & Simpangan baku & 9,58066295 & 8,793900858 \\
\hline 5 & Varians & 91,7891 & 77,3326 \\
\hline 6 & Maximum & 100 & 94 \\
\hline 7 & Minimum & 59 & 59 \\
\hline
\end{tabular}

Selanjutnya melakukan pengujian prasyarat analisis, yang dilakukan dengan uji normalitas dan uji homogenitas pada kedua kelas. Dimana uji normalitas digunakan untuk mengetahui apakah kemampuan pemahaman belajar siswa berdistribusi normal atau tidak. Sedangkan uji homogenitas digunakan untuk mengetahui apakah kedua kelompok kelas homogen atau tidak.

Untuk kelas eksperimen $\mathrm{X}^{2}$ hitung sebesar 3,405 dan harga $\mathrm{X}^{2}$ tabel dengan taraf signifikasi $\alpha=0,05$ sebesar 7,81. Sehingga $\mathrm{X}_{\text {hitung }}<\mathrm{X}^{2}$ tabel, maka $\mathrm{H}_{0}$ diterima yang berarti sampel pada kelas eksperimen berasal dari populasi berdistribusi normal. Sedangkan untuk kelas kontrol $X^{2}$ hitung sebesar 2,929 dan harga $X^{2}$ tabel dengan taraf signifikasi $\alpha=0,05$ sebesar 7,81. Sehingga $\mathrm{X}^{2}{ }_{\text {hitung }}<\mathrm{X}^{2}$ tabel, maka $\mathrm{H}_{0}$ diterima yang berarti sampel pada kelas kontrol berasal dari populasi berdistribusi normal.

Untuk harga $F_{\text {hitung }}=1,1869$ dan untuk $F_{0,05(39,39)}=1,70447$, karena $F_{\text {hitung }}<F_{0,05(39,39)}$ atau $(1,1869$ $<1,70447$ ), maka $\mathrm{H}_{0}$ diterima pada taraf signifikan $\alpha=0,05$. Ini berarti kedua sampel mempunyai varians yang sama atau homogen.

Berdasarkan hasil uji prasyarat di atas, menunjukkan bahwa data berdistribusi normal dan homogen. Maka selanjutnya data di analisis untuk pengujian hipotesis. Perhitungan uji hipotesis dilakukan untuk mengetahui ada atau tidaknya pengaruh strategi pembelajaran information search terhadap kemampuan pemahaman belajar matematika pada siswa. Maka hasil penelitian pembelajaran matematika akan dilakukan analisis data dengan menggunakan metode stastik yang membandingkan antara hasil post-test kelas eksperimen dan kontrol, sehingga diperoleh $t_{\text {hitung }}=2,8095$. Selanjutnya membandingkan harga $t_{\text {hitung dengan }}$ $t_{\text {tabel. }}$ Karena $t_{\text {hitung }}(2,8095)>t_{\text {tabel }}(1,9908)$, maka $\mathrm{H}_{0}$ di tolak dan Ha diterima, sehingga menyatakan bahwa terdapat pengaruh strategi pembelajaran information search terhadap kemampuan pemahaman belajar matematika siswa.

Kemudian untuk mengetahui seberapa besar pengaruh strategi pembelajaran information search terhadap kemampuan pemahaman belajar matematika siswa, menggunakan rumus:

$$
\begin{aligned}
& D=r^{2} \times 100 \% \\
& D=0,38222 \times 100 \% \\
& D=0,1460 \times 100 \% \\
& D=14,6 \%
\end{aligned}
$$

Sehingga besar pengaruh strategi pembelajara information search terhadap kemampuan pemahaman belajar matematika siswa adalah sebesar $14,6 \%$.

Penelitian dilakukan dengan tujuan untuk mengetahui apakah strategi pembelajaran Information Search berpengaruh terhadap kemampuan pemahaman matematika siswa Kelas X SMK BM PAB Helvetia Medan. Dari hasil penelitian analisis data pengujian hipotesis, penulis dapat mengemukakan beberapa temuan yaitu:

1. Dari hasil angket belajar matematika diperoleh rata-rata skor siswa pada pokok bahasan persamaan kuadrat sebesar 82,825 dan standart deviasi 9,58. 
3248 Pengaruh Strategi Pembelajaran Information Search terhadap Kemampuan Pemahaman Belajar Matematika Siswa - Putri Maisyarah Ammy

DOI: https://doi.org/10.31004/basicedu.v5i5.1294

2. Setelah melakukan uji t pada data post-test kelas eksperimen dan kontrol, untuk melihat apakah ada pengaruh strategi pembelajaran Information Search terhadap pemahaman matematika siswa di kelas X AK 1 SMK BM PAB Helvetia Medan, diperoleh $\mathrm{t}_{\text {hitung }}=2,8095$ dan $\mathrm{t}_{\text {tabel }}=1,9908$ untuk taraf nyata $\alpha=$ 0,05 . Hal ini menunjukkan bahwa $t_{\text {hitung }}>t_{\text {tabel, }}$ yaitu 2,8095 > 1,9908 maka Ho ditolak dan Ha diterima.

Berdasarkan data tersebut, maka peneliti menyimpulkan bahwa terdapat pengaruh strategi pembelajaran Information Search terhadap kemampuan pemahaman matematika siswa.

\section{KESIMPULAN}

Berdasarkan hasil analisis data dan temuan penelitian selama strategi pembelajaran information search dengan menekankan pada pemahaman matematika siswa, maka peneliti memperoleh kesimpulan bahwa nilai rata-rata hasil belajar kelas eksperimen adalah 82,825 dan nilai rata-rata hasil belajar kelas kontrol adalah 78,275. Data yang diperoleh adalah data berdistribusi normal dan homogen. Terdapat pengaruh strategi pembelajaran information search terhadap kemampuan pemahaman belajar matematika siswa. Besar pengaruh strategi pembelajaran information search terhadap kemampuan pemahaman belajar matematika siswa sebesar $14,6 \%$.

\section{UCAPAN TERIMA KASIH}

Penulis dalam menyusun penelitian ini mengucapkan puji syukur kepada Allah SWT atas limpahan rahmat dan hidayah dalam menyusun penelitian ini. Peneliti mengucapkan kepada orang tua, beserta keluarga yang telah memberikan dukungan secara moral dan materil. Semoga penelitian yang disusun dapat bermanfaat bagi semua. Serta pihak yang telah memberikan dukungan dalam penelitian ini.

\section{DAFTAR PUSTAKA}

Bloom, B. S., Engelhart, M. D., Furst, E. J., Hill, W. H. \& Krathwohl, D. R. T. (1956). Taxonomy Of Educational Objectives: The Classification Of Educational Goals, Handbook I Cognitive Domain. New York: Longmans, Green And Co.

Carin, A.A. \& Sund, R.B. (1997). Teaching Science Through Discovery. Columbus: Charles E. Meril Publishing Co.

David, J.R. (1976). Teaching Strategies For College Class Room, P3G.

Depdiknas. (2003). Undang-Undang RI No.20 Tahun 2003. Tentang Sistem Pendidikan Nasional. . (2006). Kurikulum Tingkat Satuan Pendidikan (KTSP) Untuk Sekolah Dasar/ MI. Jakarta: Terbitan Depdiknas

Dewi, N. (2018). Desain Model Pembelajaran Kegiatan Belajar Mengajar (KBM) Plus Di SMA Muhammadiyah 1 Palembang. Jurnal Ad-Man-Pend. 1(1), 31-36.

Djemari, M. (2011). Pengukuran, Penilaian Dan Evaluasi. Makalah Disampaikan Pada Penataran Evaluasi Pembelajaran Matematika Untuk Guru Inti Matematika Tanggal 8 - 23 November 2011 Di PPPG Matematika Yogyakarta.

Ferdianto, F. \& Ghanny, G. (2014). Meningkatkan Kemampuan Pemahaman Matematis Siswa Melalui Problem Posing. Artikel Euclid, 1(1), 47-54. Https://Doi.Org/10.33603/E.V1i1.343

Festiawan, R. (2020). Belajar Dan Pendekatan Pembelajaran. Universitas Jenderal Soedirman. Https://Osf.Io/Mpng9/Download 
3249 Pengaruh Strategi Pembelajaran Information Search terhadap Kemampuan Pemahaman Belajar Matematika Siswa - Putri Maisyarah Ammy

DOI: https://doi.org/10.31004/basicedu.v5i5.1294

Kemp, J.E. And Dayton, D.K. (1985). Planning And Producing Instructional Media. Cambridge: Harper \& Row Publishers, New York.

Kesumawati, Nila. (2008). Pemahaman Konsep Matematik Dalam Pembelajaran Matematika. Pros. Semin. Mat. Dan Pendidik. Mat. Jur. Pendidik. Mat. Fak. Mat. Dan Ilmu Pengetah. Alam Univ. Negeri Yogyakarta 229-235.

Praja, E. S., Setiyani, S., Kurniasih, L. \& Ferdiansyah, F. (2021). Analisis Kemampuan Pemahaman Matematis Siswa SMK Kelas XI Pada Materi Vektor Selama Pandemi Covid-19. Teorema Teor. Dan Ris. Mat. 6, 12-24.

Purwanti, N. (2019). Penerapan Metode Pembelajaran Pencarian Informasi Untuk Meningkatkan Hasil Belajar Matematika Materi Kesebangunan Kelas IX A SMPN 3 Kediri. Jurnal PINUS: Penelitian Inovasi Pembelajaran. 5(1), 14-20.

Rahman, A. A. (2018). Strategi Belajar Mengajar Matematika. Banda Aceh: Syiah Kuala University Press.

Sugandi, A. I. \& Bernard, M. P. (2018). Penerapan Pendekatan Kontekstual Terhadap Kemampuan Pemahaman Dan Komunikasi Matematis Siswa SMP. Artikel Analisa, 4(1), 172-178. Https://Doi.Org/10.15575/Ja.V4i1.2364

Sugiyono. (2013). Metode Penelitian Kuantitatif, Kualitatif, Dan R\&D. Bandung: Alfabeta.

Sumarmo, U. (2008). Berfikir Dan Disposisi Matematik: Apa, Mengapa, Dan Bagaimana Dikembangkan Pada Peserta Didik. FMIPA UPI 1-27.

Susanto, A. (2020). Permainan Lempar Gelang Menggunakan Model Stad Untuk Meningkatkan Pemahaman Konsep Siswa. Pros. Semin. Dan Disk. Pendidik. Dasar 1-10 (2020).

Syahrum Dan Salim. (2012). Metodologi Penelitian Kualitatif. Bandung: Citapustaka Media.

Tri Murdiyanto. (2014). Pengembangan Alat Peraga Matematika Untuk Meningkatkan Minat Dan Motivasi Belajar Matematika Siswa Sekolah Dasar. Artikel Sarwahita, 11(1), 38. Https://Doi.Org/10.21009/Sarwahita.111.07

Wardhani, S. (2010). Teknik Pengembangan Instrumen Penilaian Hasil Belajar Matematika Di SMP/Mts. Diklat Guru Pemandu/Guru Inti/Pengembang Mat. Smp Jenjang Dasar Tahun 2010 1-35. 